\title{
OUR DEAD LABOUR AND ITS RENTIERS
}

\author{
MARA FRIDELL \\ University of Manitoba \\ Piketty, Thomas. 2014. Capital in the twenty-first century. Cambridge, MA: The \\ Belknap Press of Harvard University Press. ISBN 13: 9780674430006. \\ Hardcover: 55.95 CAD. Pages: 696.
}

First, let it be noted that in a well-worn tradition of the liberal academy, Capital in the twenty-first century tosses around some pro-forma dismissals of Marx in its Introduction and Conclusion. Thomas Piketty has insisted repeatedly to the liberal media that he is not a Marxist. We hope the furry bellies of the target audience are suitably stroked.

Yet Piketty is clearly, emphatically gesturing in Capital in the twenty-first century to Marx. Is he pretending to erase and supplant the community of Marxist scholarship? Is this book a cuckoo's egg?

Piketty's voluminous, complex, collaborative analysis is not always consistent. There are surely moments when Piketty takes a posited "law" too seriously, distorting his analysis. Why does he presume to pose laws? Why the quirky redefinition of capital? If you try to apprehend capitalist relations without reference to the labour theory of value, aren't you losing sight of exploitation? Isn't Piketty's advocacy on behalf of regionallyadministered capital taxation tantamount to advocating technocracy against open, reciprocated class conflict, against the insurgency and revolution that is required to further human development? This review addresses these critical questions in the course of mapping four points of resonance between Piketty and Marxist scholarship.

\section{Deriving Dead Labour via Transhistorical Abstraction}

Piketty uses historical and international data primarily to take aim at the profession of economics' ideological and empirically-weak dismissal of economic inequality. Where these economic authorities have repeatedly attempted to give us comforting economic-convergence "laws" based on 20-30 years of optimal income data, Piketty and his coworkers distill contrasting "laws" based on 150 years of data across 
countries and across both income and wealth. These boil down to two interrelated conclusions:

First, under particular, quite capitalist conditions, a patrimonial middle class can develop. But fifty percent of the population of any nation-state will never have a share of the accumulating wealth $(260-62 ; 346-47) .{ }^{1}$ So in the capitalist system, instead of developing our human capacities, half of us or more will be exposed without buffering to deforming and stunting exploitation, marginalization, enthrallment, and man-made disasters.

Second, what you can say about capitalism based on more comprehensive data is that (with limited exceptions) capitalism provides wealth accumulation for the $1 \%$ rather than shared prosperity. Capitalist societies are currently returning to antidemocratic patrimonial capitalism. The first conclusion of the Piketty group's studies is that this return is a political achievement (20-21). In Capital in the $21^{\text {st }}$ Century, and Piketty underscores this in follow-up interviews, positing laws is mostly a device of emphasis and critique, aimed at the economics profession and whomever takes their "laws" too seriously (168; Piketty 2014b; Dolcerocca \& Terzioglu 2015). Piketty's "laws" do not usually demand naturalization or reification. They demand recognition. They convey the observed tendency of capitalism (187). Methodologically, Piketty's time framework not only shuts down the "best of all possible worlds" view authorized by the conservative economist's short data range, ${ }^{2}$ it also corrects the impression that $18^{\text {th }}-19^{\text {th }}$ century specialists would have from that era that structure, and not politics, determines inequality.

Piketty's methodology allows us to observe how inequality develops through capitalism's inherent rentier development, strengthening the capitalist class in privatecapital countries (169). Some historians dispute Piketty's methodology, his aggregating use of economic history research (Thomson 2014), and therefore the basis of his claim that capitalism produces high inequality. This constitutes a disciplinary rejection of the transhistorical abstraction methodology, which not only underlies Piketty's redefinition of capital and derivation of capital's "laws", but is also foundational to Marx's dialectical understanding (Fracchia 1991). The specification of what a phenomenon, for example capital, has in common across historical and spatial moments is distilled from the aggregated macro-historical analysis, so that an historical permutation (e.g. of capital) may be understood in comparative relief against this derived transhistorical abstraction. Marx's transhistorical abstraction methodology is designed to address the "fish describing water" problem, and to restore the capacity to ask non-trivial questions about developing

\footnotetext{
${ }^{1}$ Piketty (2014) will be referred to by page numbers only.

${ }^{2}$ To claim that capitalism $=$ democracy, for example, Kuznets creamed his sunny curve data, rather parasitically, from the start of the brief low-inequality era built on the back of socialist and labor struggle: 1913- 1948 (Piketty 2014, 13).
} 
or changing relationships in context. Sacrificing these questions to obtain the finestgrained resolution, while a higher-status approach today, poses a perennial trade-off problem (Toulmin and Goodfield 1962).

\section{The Politics of Laws}

Like Piketty, Marx also used the "laws" argumentation technique in opposition to conservative political-economy, as where Marx proposed the law of the tendency of the rate of profit to fall, and then adumbrated the political countermeasures to the tendency. "Haters" of theory as the examination of the "abstractions of value that rule our lives" have viewed this argumentation technique, along with transhistorical abstraction, as evidence of Marxist "totalization" (Noys 2015, 4). Yet Marx's "Counterpoint to the Tendency" analysis reveals an unharmonious, overdetermined, yet very political economy, in which capitalists seek to maximize their control over the accumulated dead labor by, where they can, increasing the intensity of exploitation, depressing wages below the value of labour power, cheapening elements of constant capital, and inducing population increase, globalization, and financialization (Marx [1894] 1967, Ch. 14). ${ }^{3}$ For control, "A portion of the old capital... has to give up its characteristic quality as capital, so far as acting as such and producing value is concerned," Marx explains (Marx [1894] 1967, Ch. 14).

"How is this conflict settled and the conditions restored?" (ibid.) The distribution of crisis, Marx says, is "decided through a competitive struggle in which the loss is distributed in very different proportions and forms, depending on special advantages or previously captured position" (ibid.) For Marx, capitalism's structural limitation is neither automatic revolution nor declining profit rate per se, but rather the capacity to secure capital. "Accumulate, accumulate! That is Moses and the prophets!" Marx underscores (Marx [1887] 1967, Ch. 24). Piketty takes Marx's conceptualization of capital quite seriously. As Piketty formulates Marx's crisis theory, as $\mathrm{C} / \mathrm{V}$ approaches $\infty$, so $\mathrm{r} \rightarrow$ 0 , but with the countermeasures, $r$ is sustained - at the cost of democracy (Piketty 2014b, 106-7). Bolstering a declining rate of profit or prioritizing the rate of return on capital requires political power resources: conscious capitalist class social cohesion and capacity for collective action.

\section{Alienation Gestates Exploitation}

The Marxist analysis of how capitalists combat capitalism's limits is advanced by Piketty's finding that in capitalism, the rate of return on capital can be high and at odds with growth. Marx notes that capitalists don't think in terms of preserving value

\footnotetext{
${ }^{3}$ Capital V III, Chapter 14. See also Grossmann 1992; Okishio 1961; Van Parijs 1980.
} 
formation, but in terms of profit maximization. Likewise, as Michal Kalecki (1971) observed, in the capitalist incentive system, in which fungible capital provides capitalists extra degrees of interest-maximizing strategic freedom, profits are subsumed to the ultimate priority of preserving control over capital. The absolute capitalist use value is the reproduction of exploitable labour power, Marx affirms, and of conditions under which this labour power may be exploited (Marx [1887] 1967, Ch. 25). Capital has been constituted in alienating workers from capital, and alienation is the condition of exploitation. The condition of alienation is control, the sort of stultifying grip that results in anti-labour policy in all its forms, and that has been shown to translate into a complete evisceration of democracy (Gilens and Page 2013). But capital can transcend capitalism, the order of the rentiers of labour.

Much of capital has been constituted under competitive conditions. It is motivated by what we recognize as capital proper, invested immediately for wage-labour exploitation and exclusive profit. Yet Piketty's definition of capital is that it is all things people make, except our cognitive and emotional capacities and skills-except human capital. This means that capital includes not just private capital, the sine qua non of which is exclusion, but also more inclusive forms of property: public capital, rental property, and even smallholdings like homes. It can have use value to non-capitalists (213). For Piketty, capital "reflects the state of development and prevailing social relations of each society" (47). Capital is uncertain power, for example, as in capitalization (49). But dealienated capital could be public, not private, and "useful to everyone".

Where conservative economics denies exploitation with marginalist theory, Piketty, like Marx and Kalecki, is affirming that capitalism is the compulsion to alienate from workers their class' dead labor ${ }^{4}$-assets, resources-as well as, when useful, the human capacities for communication, organization and creativity, so that capitalists can extract rent from their labour. Exploitation is the denied horror-the "worst form" of inequality, "always morally indefensible. You have to deny it rather than defend it," Therborn says $(2014,732)$. Moreover, alienation, as the Duchess of Sutherland well knew (Marx 1853), constitutes the essential social condition permitting exploitation.

\section{Solidarity, Mobilization, Scholarship}

Most of the critiques in the 685 pages of Piketty's Capital are leveled at the economics profession, but critique cannot alter the function or tight, hierarchicallyenforced content control of that community. Capital is here to galvanize everyone else. That is why Piketty is alive to the contributions of the besieged social sciences and humanities communities of scholarship, modeling the incorporation and valuation of their ways of knowing. He believes the accumulation of knowledge desperately requires

\footnotetext{
4 "The past devours the future" (Piketty 2014: 942).
} 
Arts scholars' assistance. The neglected scientific problem of triviality can only be addressed through comparative, particularly historical-comparative, method. Even the study of economic facts cannot be left to economists, whose institutionalized scientism requires their neglect. Fundamentally, both economics' scientism and other scholars' dismissal of science work hand in glove, abandoning agenda-setting to more powerful networks (575).

Piketty likewise rejects the market-niche ideology that policy is for liberals only while social movement is the proper object of Leftist concern. "It would be a big mistake if some on the left believed, "Progressive taxation, that's a technocratic thing. We don't really care. We care about revolution, and capital ownership." This is partly because progressive tax reform, like any effort to provide the footing and resources to the working class for it to pursue social and economic rationality, is only possible as the result of "huge mobilization." For example, "the income tax in European countries was accepted by the elite only after World War I and the Bolshevik Revolution as part of a counter-struggle against its influence" (Dolcerocca \& Terzioglu 2015). Progressive taxation is but one aspect of producing "a regime based on transparency, on information about income and wealth that is necessary for the workers involvement in management." Also necessary are new forms of governance, "new forms of ownership," and "new forms of sharing power between those who own capital and those who own their labor... The shareholder company is not the end of history" (ibid.).

In Capital Vol. 3, Chapter 14, Marx began to tally the ways in which, at the point where capitalist interests dislodge from economic growth, capitalists and their political agents use capital to keep the $99 \%$ alienated from capital. Here is where Piketty picked up Marx's agenda. Piketty's comparative, transhistorical research confirms that capitalist incentives inherently drive development toward a belligerent, high-inequality society, congealing rigid castes and the pseudo-speciation of racialization, subjugating women with the traditional protectionist devil's bargain, wiping out developmental democratic institutions and dispositions, and depleting material well-being, as the ecologists and social epidemiologists have documented. Liberalism, whether conservative or genteel, cannot contain capitalists' strategic breadth and compulsion to control. Only revolution and anticolonialism, socialist realism, as Piketty says "a big fight and a big mobilization," and sometimes "violent shocks" (Dolcerocca \& Terzioglu 2015) can do that. ${ }^{5}$

Piketty earns the right to call his book Capital not through rigorous Marxist scholarship, but due to his propensity to understand social systems as developing, though not necessarily maturing; due to his ability to see the boxes to think outside them; and due to his effort to prioritize solidarity and mobilization. This isn't the heir we were expecting, but he may be an heir we need at the moment.

\footnotetext{
${ }^{5}$ Disruption is what puts a brake on rentier parasitism (Piketty 2014: 147-158).
} 


\section{Author's Note}

My heartfelt appreciation extends to the exemplary scholars Majorie Griffin Cohen, Elaine Coburn, Radhika Desai, Mark Hudson and Erik Thomson, for their collegial support in the process of writing this essay.

\section{References Cited}

Aboim, Sofia. 2014. "The killing fields of inequality: Interview with Goran Therborn." Analise Social 49 (212): 729-735.

Dolcerocca, Antoine and Gokhan Terzioglu. 2015. "Interview: Thomas Piketty responds to criticisms from the Left." Potemkin Review, January. http://www.potemkinreview.com/pikettyinterview.html.

Fracchia, Joseph. 1991. "Marx's Aufhebung of philosophy and the foundations of a materialist science of history." History and Theory 30 (2): 153-179.

Gilens, Martin \& Benjamin I. Page. 2014. “Testing theories of American politics: Elites, interest groups and average citizens." Perspectives on politics 12(3): 564-581.

Itoh, Makoto. 2015. "Political economy of disparities re-expanded: Comments on Capital in the Twenty-first Century," Geopolitical Economic Research Group paper, presented September 26, Winnipeg.

Kalecki, Michal. 1971. Part III, pp. 138-183 in Selected essays on the dynamics of the capitalist economy, 1933-1970. Cambridge, UK: Cambridge University Press.

Marx, Karl. 1853. “The Duchess of Sutherland and Slavery." The People’s Paper 45, March 12.

Marx, Karl. (1887) 1967. Capital Vol. 1: A critical analysis of capitalist production. New York: International Publishers.

Marx, Karl. (1894) 1967. Capital Vol. 3: The process of capitalist production as a whole. New York: International Publishers. 
Noys, Benjamin. 2015. "Hating Theory," available at https://www.academia.edu/15479218/Hating Theory.

Piketty, Thomas. 2014. Capital in the twenty-first century. Cambridge, MA: The Belknap Press of Harvard University Press.

Piketty, Thomas. 2014b. “Dynamics of inequality.” New Left Review 85: 103-116.

Thomson, Erik. 2014. "Piketty," Geopolitical Economic Research Group discussion paper, presented September 26, Winnipeg.

Toulmin, Stephen and June Goodfield. 1962. The architecture of matter. Chicago: The University of Chicago Press. 